Volume 9, Number 1, 2021, Pages $10-18$
JRASD
Journal Homepage: https://journals.internationalrasd.org/index.php/pjhss

\title{
Impact of Taxation on Foreign Direct Investment: Empirical Evidence from Pakistan
}

Muhammad Nouman Shafiq ${ }^{1}$, Liu Hua ${ }^{2}$, Muhammad Azhar Bhatti ${ }^{3}$, Seemab Gillani ${ }^{4}$

${ }^{1}$ PhD Scholar, School of Economics and Finance, Xi'an Jiaotong University, Xi'an, Shaanxi Province, China Email: muhammadnoumanshafiq@yahoo.com

2 Assistant Professor, School of Economics and Finance, Xi'an Jiaotong University, Xi'an, Shaanxi Province, China Email: liuhua123@xjtu.edu.cn

3 Associate Lecturer, Department of Economics, The Islamia University of Bahawalpur Pakistan Email: azhar.bhatti219@gmail.com

${ }^{4}$ PhD Scholar, School of Economics and Finance, Xi'an Jiaotong University, Xi'an, Shaanxi Province, China Email:seemabgillani@yahoo.com

\begin{tabular}{|c|c|}
\hline ARTICLE INFO & \\
\hline Article History: & \\
\hline Received: J & June 13,2021 \\
\hline Revised: & June 23, 2021 \\
\hline Accepted: & June 30,2021 \\
\hline Available Online: & June 30,2021 \\
\hline
\end{tabular}

\section{Keywords:}

Economic Growth

Foreign Direct Investment

Taxation

Trade

\section{JEL Classification Codes:}

F21, H20, O40, P33

\section{ABSTRACT}

Foreign direct investment plays a vital role in promoting economic growth, especially for developing economies. It causes improvement in the different sectors such as education, healthcare, manufacturing industries, and creates more jobs. The speed of FDI inflows has been increasing in Pakistan each year. In order to attract more FDI, many countries try to reframe their tax policies by introducing different tax incentives such as tax holidays, investment allowances, exemptions, deductions, etc. The purpose of the present paper is to find the implication of taxation in the decision of FDI inflows in Pakistan. Time series data is used spanning over 1985 to 2020. The data was obtained from two sources: the World Development Indicator (WDI) and the Economic Survey of Pakistan. Auto-Regressive Distributed Lag (ARDL) and Error Correction Model(ECM) techniques are used for empirical analysis. The study concludes that low taxes motivate foreign investor's contribution and the long-run relationship between taxes and FDI in Pakistan. Other control variables such as GDP growth, trade openness, and exchange rate have a positive impact on FDI. It is suggested that decision-makers should direct policies to reduce the taxes to welcome FDI in Pakistan. In this regard, the government needs to reconsider its priorities while making policies in favour of FDI.

(C) 2021 The Authors, Published by iRASD. This is an Open Access Article under the Creative Common Attribution Non-Commercial 4.0

Corresponding Author's Email: muhammadnoumanshafiq@yahoo.com

\section{Introduction}

The country's current economic conditions decide its future(Nawaz, Azam, \& Bhatti, 2019). Any country's economy gets support from several factors for its survival and growth like FDI, inflation, trade, import, export, and tax revenue etc. Almost every government keen to invite FDI for its country. The International Monetary Fund states that FDI refers to an investment made to secure long-term interest by the investor in enterprises that operates in another country. FDI is a direct investment to a foreign establishment, an individual or a set of entities that can regulate or manage by the foreign enterprise(Kolodkin, 2017). Historically, technological advancement paved the way to the emergence of faster means of communication and transport, which led to the movement of investors across boundaries(Pritchard, 1996).

FDI is a key factor of external finance for developing countries, as they can get finance from richer countries(Kolodkin, 2017; Yang \& Shafiq, 2020). Moreover, FDI offers various benefits to the country, such as providing long-term capital necessary for the host nation's economic development. Such as, creation of new workplaces, bringing new technologies, providing greater access to foreign markets, bringing new managerial skills, attracting companies from innovative sectors, bringing 'clean technologies which can improve 
environmental conditions, increasing employment and level of wages and providing a positive impact on trade balance(Misra, 2012).

FDI supports the country's economic development by strengthening its human capital, which is the most critical factor in Research and Development. It causes an increase in innovation and competition, which boosts technological progress and productivity. Further, it leads to overall economic growth in the country(Grossman \& Helpman, 1991).Several reasons stand behind the investment of one country in another country, i.e., cost of production, quality products, and reduced lead time as internationalization theory states that one of the prime reasons behind the FDI of any country is the economy of scale, which reduces the cost of production (Siddique, Ansar, Naeem, \& Yaqoob, 2017).

Another influential factor in the country's economic growth is tax revenue. Tax is the obligatory charge imposed by the government on the people. The tax is levied on the people's income, properties, and other related factors (Ojong, Anthony, \& Arikpo, 2016). Taxation is important because it funds necessary activities and benefits the people of the country(Holmes, 1904).According to the definition given by United Nations Conference on Trade and Development (UNCTAD), tax incentives are opportunities that reduce the tax burden of a party and encourage them to invest in a project or sector. The tax incentives may contain reduced tax rates, carry forward losses, tax holidays, and reduced tariffs(Alegana, 2014). On the other hand, tax expenditures are losses that a government undertakes by providing tax deductions, allowances, exemptions, tax credits or preferential tax rates (Gruber, 2005).

Tax incentives can be broadly divided into four types; tax holidays, tax credit and investment allowance, timing differences, and reduced tax rates. Tax holidays exempt the new companies from tax for a particular period of time, and investment tax credits provide deductions from tax payable, whereas investment allowances are deductions that reduce taxable income. Timing differences may contain the deduction in the first year or a shorter period of depreciation. However, reduced tax rates are the most common form of tax incentive used by many countries to encourage investment(Brodzka, 2013).Because of FDI prospective benefits, policymakers constantly inspect their tax directions to fascinate the more foreign investment. Tax policies support the FDI, as an outbound investment provides effective entrance into the international markets and makes enough capable to achieve the economies of scale, which lead to an increase in net domestic income.

Simultaneously, governments are trying to balance the desire to provide a competitive tax environment for FDI to confirm that a significant share of domestic tax is collected from international businesses. At the same time, taxes are known as a key factor to decide an investment location. As a result, FDI is attracted to countries offering access to world markets and opportunities for profit, an expectable and non-discriminatory legal framework, macroeconomic stability, skilled and efficient labor markets, and developed infrastructure. All these factors influenced the long-term profitability of a project (Clark, 2008).

In developing economies, policymakers face a serious challenge to attract foreign direct investment. Moreover, the complex issue is to decide: How taxation affects the FDI? How do exchange rate and interest rate cause the improvement in FDI? What is the important policy consideration that helps the taxation of outbound investment? How countries react to the pressure to reduce taxes on FDI? Pakistan as a developing economy has grown over the last three decades on average more than 5\% (World Bank, 2018), and still, there is a need for financial capital for sustained future growth. So, it is vital to explore the crucial determining factors of the FDI in Pakistan. The trend of FDI in Pakistan is rising from $\$ 1.74$ billion (2018) to $\$ 2.22$ billion (2019). However, due to the global medical emergency, FDI inflows decreased to $\$ 1.395$ billion $(2021)^{1}$. Nevertheless, the biggest source of FDI comes from China. Thus, the objective of the present study is to examine the impact of taxation on foreign direct investment (FDI) in the case of Pakistan and suggests policies based on the finding of the study.

The organization of the current study consists of six sections. Section 2 describes the existing literature on the tax rate and FDI, and Section 3 briefly describes the model and

${ }^{1}$ http://www.businessworld.in/article/Pakistan-s-FDI-Falls-35-In-Nine-Months/21-04-2021-387178 11 
econometric techniques used for the analysis. Section 4 interprets the findings obtained from ARDL and ECM model. Finally, in section 5, the conclusion is stated and provides suitable policy suggestions to fascinate more FDI in Pakistan.

\section{Literature Review}

The objective of the literature review is to obtain studies performed in relevant fields (Leady, 1989). It gives the guidelines to accomplish the purposed research area considering the conclusions drawn from the past research work. It also checks the unnecessary recurrences. Consequently, the literature review contributes a base upon which the coming analysis is yet to be developed (Borg \& Gall, 1984).

Earlier literature has identified the dynamic role of FDI in economic development and growth, knowledge and technology transfer, upgrade productivity, capital inflow, and job opportunities. Consequently, FDI inflows in the economy define through the tax rate(Carkovic \& Levine, 2005; Contractor, Dangol, Nuruzzaman, \& Raghunath, 2020; Hartman, 1984).In this regard, many countries provide different type of incentives to the firms of other countries to investing their economies. (Gorg and Greenaway (2004).

Hartman (1984) examined pioneer work on the tax effects on FDI in the U.S by using 15 years of data (1965-1979). Findings obtained from the aggregate time-series model state that foreign investment in the U.S. had a strong and significant association with the domestic tax policy changes. The same line of work done by Slemrod (1990)in the USA by using a standard model. The study concluded that the US efficient tax rate harmed FDI.

Aqeel, Nishat, and Bilquees (2004) investigated the factors of FDI in Pakistan. They showed that different financial, fiscal, and trade sector liberalization factors had impacted FDI in Pakistan. The study used secondary data collected from 1961 to 2003 with co-integration and error correction techniques; and presented that low tariff rate on imports and corporate tax rate significantly impact the FDI growth. Moreover, the exchange rate coefficient was positive, suggesting that when the rupee's value appreciates, FDI is enhanced as investors see it as a positive sign for the country and expect more returns.

Du, Harrison, and Jefferson (2014) examined different changes in China's industrial policies from 1998-2007. First, the sole trader ship was changed or liquidated by thousands of public sector enterprises. Second, to increase FDI, the corporate tax rate decreased to $15 \%$ for overseas firms, however being charged by $33 \%$ from local ones. The average tariff rate had been declined by $9.4 \%$ after becoming a WTO member in 2001. As a result ofthe lower corporate tax rate for the overseas firms than the domestic firms, China became the top destinations for FDI.

Mandinga (2015) used panel data of 22 (SIDS) Small Island Developing States for 2004-2013 and showed that an increase of 10\% corporate tax rate reduced FDI by $3.5 \%$ in the short run and by $4.7 \%$ in the long run. Therefore, the study proposed that SIDS countries should decrease their corporate tax rate to captivate more FDI. Correspondingly, Demirhan and Masca (2008) applied an econometric model on cross-sectional data of 38 less developed countries from 2000-2004 and found that corporate and inflation tax rate had a significant negative impact on FDI. A similar line of work done by Ang (2008), the study concluded that FDI inflows response undesirably to enhance corporate tax rate.

Gastanaga, Nugent, and Pashamova (1998) analyzed the factors affecting the FDI by using the data of 49 developing economies in a multivariate analysis from 1970-95. The study concluded that the corporate tax rate had a negative influence on FDI. The location for the investment has become a crucial variable that affects the tax rates. In the existence of many opportunities existing for production, it is not unexpected that decisions greatly depend on a lower tax rate of location. Undoubtedly international tax policies have a positive effect on the size and place of FDI. The present international evidence proved that tax rate differences decided the FDI inflows in an economy (Hines Jr, 1999).

Past studies showed the vital contribution of taxation in the FDI inflow in developed and developing economies(Aqeel et al., 2004; Du et al., 2014; Hartman, 1984; Mandinga, 2015; 
Slemrod, 1990). The home country tax rate is a major factor along with the host country. Even though a decrease in corporate tax rate attracts more FDI, it is not the only element of the FDI inflow. Different factors such as labor cost, market size, trade openness, political stability, organized and monitoring environment are the additional main factors of the FDI.

FDI inflow found to be much important for developing countries than the developed countries due to their prerequisite for foreign capital, economic development and growth, technology and transfer of business know-how. Nevertheless, many past studies have found the determinants of FDI in developed economies, while this research is still limited in developing economies. Here, the current study points out the key factors of FDI in Pakistan, which are useful with certain modification by policymakers to attract more FDI in Pakistan.

\section{Data and Methodology}

The formation of the appropriate methodology and suitable techniques are vital for any research study. Thus, this section explains the methodology and techniques used for the current analysis. In order to explore the short-run and long-run impact of taxation on FDI in the case of Pakistan, time-series data comprising of 1985 to 2020 is used. Data is collected from World Development Indicators (WDI, 2021) for all variables except tax rate, and its data is taken from the Economic Survey of Pakistan. The functional form for the current analysis is as:

$$
F D I=f(T A X, G D P G, T R A D E O, E X R, I N R) \ldots(1)
$$

Here Foreign Direct Investment (FDI) is the dependent variable while tax rate (TAX) is the main independent variable. Moreover, control variables consist of GDP growth (GDPG), trade openness (TRADEO), the exchange rate (EXR), and interest rate (INR). Therefore, equation 1 can be written in a time-series form as:

$$
F D I_{t}=\beta_{0}+\beta_{1} T A X_{t}+\beta_{2} G D P G_{t}+\beta_{3} T_{R A D E O_{t}}+\beta_{4} E X R_{t}+\beta_{5} I N R_{t}+\varepsilon_{t} \ldots(2)
$$

In the above equation, $\beta_{0}=$ intercept, $\beta_{1}$ to $\beta_{5}$ coefficients indicate a change in foreign direct investment due to change in the tax rate, GDP growth, trade openness, exchange rate, and interest rate, respectively. Subscript t represents the time period from 1985 to 2020, and $\boldsymbol{\varepsilon}$ indicates the error term. Table A (in appendix) shows the list of variables, including dependent, independent and control variables used for the analysis.

Literature has proposed various techniques to find the integration relationship between variables, among them popular techniques are the Residual based approach by Engle and Granger (1987) and the Maximum Likelihood approach by Johansen and Juselius (1990). All variables with the same order of integration are required for the suitability of both approaches. However, an issue arises with different order of integration as in the current analysis. In order to resolve this issue, the Autoregressive Distributed Lag (ARDL) approach by Pesaran, Shin, and Smith $(1996,2001)$ is used for the analysis. ARDL is applicable for I(0), I(1) and mixed order of integration.

To check the stationarity of data is the first step in time series analysis to avoid spurious regression. The Augmented Dicky Fuller test is used to check the stationarity of data. ARDL is used to capture long-run relationships between variables in co-integration, whereas the Error Correction Model (ECM) is applied to capture short-run dynamics. The bound test allows us to include different lags of each variable in the model. Equation 3 represents the functional form of ARDL as:

$$
\begin{aligned}
\Delta(F D I)_{t}= & \alpha_{0}+\sum_{i=1}^{p} \alpha_{1} \Delta(T A X)_{t-1}+\sum_{i=0}^{p} \alpha_{2} \Delta(G D P G)_{t-1}+\sum_{i=0}^{p} \alpha_{3} \Delta(T R A D E O)_{t-1}+\sum_{i=0}^{p} \alpha_{4} \Delta(E X R)_{t-1}+\sum_{i=0}^{p} \alpha_{5} \Delta(I N R)_{t-1}+ \\
& \gamma_{1}(T A X)_{t-1}+\gamma_{2}(G D P G)_{t-1}+\gamma_{3}(T R A D E O)_{t-1}+\gamma_{4}(E X R)_{t-1}+\gamma_{5}(I N R)_{t-1}+v_{i}
\end{aligned}
$$

Here alphas ( $a_{1}$ to $a_{5}$ ) indicate the short-run dynamics and gammas ( $\gamma_{1}$ to $\left.\gamma_{6}\right)$ represent the long-run relationship. Rejection of null hypothesis $\left(\gamma_{1}=\gamma_{2}=\gamma_{3}=\gamma_{4}=\gamma_{5}=\gamma_{6}=0\right)$ indicates the existence of co-integration then move to check short-run and long-run dynamics. To check the existence of a long-run relationship between variables by using $\mathrm{F}$-test. In case the F-statistic value is greater than a critical value of the upper bound, then variables are cointegrated. On the other hand, while a critical value of a lower bound is greater than F13 
statistic, then variables used in the model are not co-integrated. Moreover, the F-statistic value lies between upper and lower bounds, and then the result yields an inconclusive finding.

\section{Results and Discussion}

In this section, descriptive statistics and empirical results are discussed to find the impact of taxation on foreign direct investment in Pakistan.

\subsection{Descriptive Statistics}

Descriptive statistics are very significant because if the data is in a raw format, it is very difficult to understand the data trend. Hence, the summary of the descriptive statistics shows the data in a more meaningful manner that is easily interpretable. Furthermore, the descriptive statistics table shows the total observations, mean value, standard deviation, and range of the data (minimum and maximum value), which helps in further estimation. Table 1 explains the summary statistics of all the selected variables used for the analysis.

Table 1: Summary statistics of all variables

\begin{tabular}{lccccc}
\hline Variables & Obs. & Mean & Std. Dev. & Min & Max \\
\hline $\begin{array}{l}\text { Dependent Variable } \\
\text { Foreign Direct Investment }\end{array}$ & 36 & .987111 & .792039 & .3314527 & 3.668323 \\
\hline & \multicolumn{7}{c}{ Independent Variable } \\
\hline Tax rate & 36 & 12.00556 & 1.724271 & 9.1 & 14.6 \\
\hline GDP growth & 36 & 4.452779 & 1.871098 & .9888294 & 7.705898 \\
Trade Openness & 36 & 32.30234 & 3.600447 & 25.30623 & 38.49932 \\
Real effective exchange rate & 36 & 115.4737 & 21.37556 & 96.48717 & 200.4289 \\
Real interest rate & 36 & 1.690233 & 3.645495 & -5.079301 & 8.321459 \\
\hline
\end{tabular}

\subsection{Econometric Analysis}

Table 2 represents the results of the Augmented Dicky Fuller test, which indicates that all variables are integrated at order zero or one. Hence, ARDL Bound test is the application here with no variable is integrated at order 2, which makes F-statistics complicated.

Table 2: Augmented Dickey Fuller Test

\begin{tabular}{ccccc}
\hline Variables & Level of Integration & t-Statistic & Prob.* & Decision \\
\hline FDI (Foreign Direct Investment) & First Difference & -3.895169 & $0.0233^{*}$ & $\mathrm{I}(1)$ \\
TAX (Tax rate) & First Difference & -7.494636 & $0.0000^{* *}$ & $\mathrm{I}(1)$ \\
GDPG (GDP growth) & Level & -4.123384 & $0.0134 * *$ & $\mathrm{I}(0)$ \\
TRADEO (Trade openness) & First Difference & -5.810965 & $0.0002 * *$ & $\mathrm{I}(1)$ \\
EXR (Exchange Rate) & Level & -6.496870 & $0.0000^{* *}$ & $\mathrm{I}(0)$ \\
INR (Interest Rate) & Level & -4.621674 & $0.0039 * *$ & $\mathrm{I}(0)$ \\
\hline
\end{tabular}

Note: "The asterisks $* *$ and $*$ showed that the coefficient is significantly different from zero at $1 \%$ and $5 \%$ probability, respectively."

For ARDL, the first step is to find lag length criteria, and minimum lags are suitable for time series analysis to avoid losing degree of freedom. Table 3 presents the lag order selection criteria.

Table 3: VAR Lag Order Selection Criteria (TAX and FDI)

\begin{tabular}{ccc}
\hline Lag & AIC & SC \\
\hline 0 & 27.81819 & 28.08755 \\
1 & 23.56501 & $25.45051^{*}$ \\
2 & $23.25056^{*}$ & 26.75221 \\
\hline
\end{tabular}

*Indicates lag order selected by the criterion, Akaike Information Criterion (AIC) and Schwarz Information Criterion (SC)

Table 4 shows that the calculated value from the ARDL model is 4.830319 , which is larger than a critical value of the upper bound. Therefore, rejection of the null hypothesis indicates that there existsa long-run relationship.

The upper part of table 5 shows the coefficients of the ARDL model. The lower part of the table provides the coefficient of the Error Correction Model, which indicates the short-run impact between variables. There occurs a negative relationship between taxes and FDI. Whenever the tax rate increases, FDI decreases in the country. Other control variables, i.e. GDP growth, exchange rate, and trade openness, are positively related to FDI. The impact of 
interest rate is found insignificant in the model. Moreover, taxes, GDP growth, exchange rate and trade openness have long-run association with FDI.

Table 4: ARDL bounds Testing Analysis

\begin{tabular}{ccc}
\hline Model Estimated & \multicolumn{2}{c}{ Model (FDI, TAX, GDPG, TRADEO, EXR, INR) } \\
\hline F-Statistics & \multicolumn{3}{c}{4.830319} \\
Selected Lag Length (Criteria) & \multicolumn{3}{c}{ (SC) } \\
\hline \multicolumn{3}{c}{ Pesaran et al. (2001) } \\
Critical bound values & Lower Bound Value & Upper Bound Value \\
$10 \%$ & 2.26 & 3.35 \\
$5 \%$ & 2.62 & 3.79 \\
$2.5 \%$ & 2.96 & 4.18 \\
$1 \%$ & 3.41 & 4.68 \\
\hline
\end{tabular}

Table 5: ARDL Model Long-run and Short-run Results

\begin{tabular}{|c|c|c|c|}
\hline \multirow{3}{*}{ Variables } & \multicolumn{3}{|c|}{ Dependent Variable: Foreign Direct Investment (FDI) } \\
\hline & \multicolumn{3}{|c|}{ Long-run Results } \\
\hline & Coefficient & t-Statistic & Prob. Value \\
\hline Tax rate & -0.017045 & -2.110446 & $0.0439 * *$ \\
\hline GDP Growth & 0.874153 & 1.993490 & $0.0564 *$ \\
\hline Trade Openness & 0.141241 & 2.376843 & $0.0245 * *$ \\
\hline Exchange Rate & 0.015753 & 1.940985 & $0.0628^{*}$ \\
\hline Interest Rate & -0.128736 & -1.561367 & 0.1297 \\
\hline \multicolumn{4}{|c|}{ Short-run Results } \\
\hline ECM & -0.255891 & -2.638794 & $0.0134 * * *$ \\
\hline $\mathrm{D}(\operatorname{Tax})$ & 0.009671 & 0.181121 & 0.8576 \\
\hline D(GDP Growth) & 0.074559 & 1.766740 & $0.0886 *$ \\
\hline $\mathrm{D}$ (Trade openness) & 0.044815 & 1.941877 & $0.0627 *$ \\
\hline D(Exchange Rate) & 0.066311 & 2.658531 & $0.0130 * * *$ \\
\hline $\mathrm{D}$ (Interest Rate) & -0.037108 & 1.916873 & $0.0659 *$ \\
\hline \multicolumn{4}{|c|}{ Diagnostic Tests } \\
\hline \multicolumn{2}{|c|}{$\begin{array}{l}\text { Test } \\
\end{array}$} & F-statistic value & Prob. value \\
\hline \multirow{3}{*}{\multicolumn{2}{|c|}{$\begin{array}{c}\text { J-B Normality Test } \\
\text { Breusch-Godfrey Serial: Correlation LM Test } \\
\text { Heteroskedasticity Test: ARCH }\end{array}$}} & 1.374496 & 0.5029 \\
\hline & & 0.388563 & 0.5385 \\
\hline & & 0.066796 & 0.7977 \\
\hline
\end{tabular}

The negative effect of the tax rate on FDI is the result of high tax rates, which makes the investors reluctant to do businesses because it reduces the profits of the investors (Agostini, 2007; Ang, 2008; Aqeel et al., 2004; Gastanaga et al., 1998; Mandinga, 2015). Therefore, tax is the main determinant in the decision making of FDI as investors compare taxes across countries (Clark, 2008).

Control variables, including GDP growth, trade openness, and exchange rate, significantly positively influence the level of foreign direct investment (Aizenman \& Noy, 2006; Alshamsi \& Azam, 2015; Bilawal et al., 2014; Ghosh, 2007). Economic growth positively affects FDI (Grosse \& Trevino, 1996; Veugelers, 1991) as high economic growth promotes more economic activities, which further attracts FDI in the recipient economy. In addition, trade openness upsurges the scale of production, which attracts more FDI in the host country (Asiedu, 2002; Greenaway, Sapsford, \& Pfaffenzeller, 2007; Liargovas \& Skandalis, 2012).

Weaker currency state invites more FDI inflows (Blonigen, 1997; Froot \& Stein, 1991). This high exchange rate raises FDI inflows as depreciated currency reduces wages and production costs in the home country. This leads to attracting foreigners to invest due to location benefit and cheap labor. Here, foreigners benefit from industrious capacity investment from location benefit and attain a higher rate of return due to low wages and cost of production in the host country (Goldberg, 2009). Moreover, the effect of interest rate is found negative and insignificant in explaining the impact of interest rate on FDI in Pakistan.

The error correction term is statistically significant, with a negative sign at a $5 \%$ level of significance. Likewise, the coefficient of ECM is -0.255891 , stated in the table above indicates that the speed of adjustment from a short-run disequilibrium to a long-run equilibrium is $25 \%$ in a year. Furthermore, the model satisfies all of the stated diagnostic tests. Therefore, the analytic tests are provided at the end of the table to confirm the appropriate model selection. 


\section{Conclusion and Policy Suggestions}

According to the results and literature, it can be concluded that FDI plays a key role in contributing to economic growth and development by investing in different sectors. It also has an indirect positive impact on the transfer of technology, employment, training, and skills which all contribute to the long-term development of the host economies. In this regard, introducing tax reforms or tax inducement is an important factor in attracting foreign direct investment. Literature also suggests that reduction in tax rate is the most preferred method because of simplicity in its application. However, there is no denying that there are other key factors that are considered important in attracting FDI, such as the country's political environment, infrastructure, labor market conditions, availability of resources, financial factors, government and legal factors, etc.

The current study found the influence of tax rate on FDI in Pakistan from 1985 to 2020.Data is collected from two sources: World Development Indicators (WDI) and Economic Survey of Pakistan. ARDL approach is used to explore the long-run association between modelled variables. Results indicate that there is a long-run association between tax rate and FDI in Pakistan. In the case of other control variables, including GDP growth, trade openness, and exchange rate have a significant impact on FDI, whereas interest rate impact is negative and insignificant.

Pakistan should focus the robust efforts to fascinate more FDI. It is suggested that policymakers should make policies to reduce the taxes to welcome FDI in Pakistan. The government needs to reconsider its priorities while making policies in favor of FDI. The prime concern must be set to classify the areas which may attract more FDI. There is no such unique strategy of development that will benefit all the countries at all times. The government abilities must be judge and evaluate in the process of making policies.

Other macroeconomic variables could be used in the analysis. For example, the macroeconomic factors such as law and order situation, political stability, local business environment, economic policies, and American dependence effect also substantially affect FDI in Pakistan. But all these variables could not be assessed due to the data and time limitation as in the present study. Therefore, it is recommended that these factors may be analyzed in future studies.

\section{References}

Agostini, C. A. (2007). The impact of state corporate taxes on FDI location. Public Finance Review, 35(3), 335-360.

Aizenman, J., \& Noy, I. (2006). FDI and trade-Two-way linkages? The quarterly review of economics and finance, 46(3), 317-337.

Alegana, H. M. (2014). The effect of tax incentives on economic growth in Kenya. University Of Nairobi,

Alshamsi, K. H., \& Azam, M. (2015). The impact of inflation and GDP per capita on foreign direct investment: the case of United Arab Emirates. Investment Management and Financial Innovations(12, Iss. 3 (contin.)), 132-141.

Ang, J. B. (2008). Determinants of foreign direct investment in Malaysia. Journal of policy modeling, 30(1), 185-189.

Aqeel, A., Nishat, M., \& Bilquees, F. (2004). The determinants of foreign direct investment in Pakistan [with comments]. The Pakistan Development Review, 651-664.

Asiedu, E. (2002). On the determinants of foreign direct investment to developing countries: is Africa different? World Development, 30(1), 107-119.

Bilawal, M., Ibrahim, M., Abbas, A., Shuaib, M., Ahmed, M., Hussain, I., \& Fatima, T. (2014). Impact of exchange rate on foreign direct investment in Pakistan. Advances in Economics and Business, 2(6), 223-231.

Blonigen, B. A. (1997). Firm-specific assets and the link between exchange rates and foreign direct investment. The American Economic Review, 447-465.

Borg, W. R., \& Gall, M. D. (1984). Educational research: An introduction.

Brodzka, A. (2013). Tax incentives in emerging economies. Business Systems \& Economics, $3(1), 26-36$. 
Carkovic, M., \& Levine, R. (2005). Does foreign direct investment accelerate economic growth. Does foreign direct investment promote development, 195.

Clark, W. (2008). Tax effects on foreign direct investment. Organization for Economic CoOperation and Development.

Contractor, F. J., Dangol, R., Nuruzzaman, N., \& Raghunath, S. (2020). How do country regulations and business environment impact foreign direct investment (FDI) inflows? International Business Review, 29(2), 101640.

Demirhan, E., \& Masca, M. (2008). Determinants of foreign direct investment flows to developing countries: a cross-sectional analysis. Prague economic papers, 4(4), 356369.

Du, L., Harrison, A., \& Jefferson, G. (2014). FDI spillovers and industrial policy: The role of tariffs and tax holidays. World Development, 64, 366-383.

Engle, R. F., \& Granger, C. W. (1987). Co-integration and error correction: representation, estimation, and testing. Econometrica: journal of the Econometric Society, 251-276.

Froot, K. A., \& Stein, J. C. (1991). Exchange rates and foreign direct investment: an imperfect capital markets approach. The Quarterly Journal of Economics, 106(4), 1191-1217.

Gastanaga, V. M., Nugent, J. B., \& Pashamova, B. (1998). Host country reforms and FDI inflows: How much difference do they make? World Development, 26(7), 1299-1314.

Ghosh, I. (2007). The Relation between Trade and FDI in Developing Countries--A Panel Data Approach. Global Economy Journal, 7(3), 1850114.

Goldberg, L. S. (2009). Exchange rates and foreign direct investment. The Princeton encyclopedia of the world economy, 1(1), 393-396.

Gorg, H., \& Greenaway, D. (2004). Much ado about nothing? Do domestic firms really benefit from foreign direct investment? The World Bank Research Observer, 19(2), 171-197.

Greenaway, D., Sapsford, D., \& Pfaffenzeller, S. (2007). Foreign direct investment, economic performance and trade liberalisation. World Economy, 30(2), 197-210.

Grosse, R., \& Trevino, L. J. (1996). Foreign direct investment in the United States: An analysis by country of origin. Journal of international business studies, 27(1), 139-155.

Grossman, G. M., \& Helpman, E. (1991). Innovation and growth in the global economy: MIT press.

Gruber, J. (2005). Public finance and public policy: Macmillan.

Hartman, D. G. (1984). Tax policy and foreign direct investment in the United States. National tax journal, 37(4), 475-487.

Hines Jr, J. R. (1999). The case against deferral: a deferential reconsideration. National tax journal, 385-404.

Holmes, T. R. (1904). A History of the Indian Mutiny: And of the Disturbances Which Accompanied It among the Civil Population: Macmillan and Company, limited.

Johansen, S., \& Juselius, K. (1990). Maximum likelihood estimation and inference on cointegration-with appucations to the demand for money. Oxford Bulletin of Economics and statistics, 52(2), 169-210.

Kolodkin, B. (2017). What is Foreign Direct Investment? . About. com, US Foreign Policy.

Leady, P. (1989). Principal research and design. In: New York. McMillan \& co.

Liargovas, P. G., \& Skandalis, K. S. (2012). Foreign direct investment and trade openness: The case of developing economies. Social indicators research, 106(2), 323-331.

Mandinga, C. A. V. C. (2015). The effect of corporate income tax rate on foreign direct investment in small island developing states.

Misra, S. (2012). Study of Implications of FDI on Indian Economy. Postmodern Openings, $3(12), 153-170$.

Nawaz, M. A., Azam, A., \& Bhatti, M. A. (2019). Natural Resources Depletion and Economic Growth: Evidence from ASEAN Countries. Pakistan Journal of Economic Studies, 2(2), 37-54.

Ojong, C. M., Anthony, O., \& Arikpo, O. F. (2016). The impact of tax revenue on economic growth: Evidence from Nigeria. IOSR Journal of economics and finance, 7(1), 32-38.

Pesaran, M. H., Shin, Y., \& Smith, R. J. (1996). Testing for the'Existence of a Long-run Relationship'. Retrieved from

Pesaran, M. H., Shin, Y., \& Smith, R. J. (2001). Bounds testing approaches to the analysis of level relationships. Journal of applied econometrics, 16(3), 289-326.

Pritchard, R. (1996). The Contemporary Challenges of Economic Development. Economic Development, Foreign Investment and the Law: Issues of Private Sector Involvement, Foreign Investment and the Rule of Law in a New Era, the Kluwer Law International, International Bar Association, London, 1. 
Siddique, H. M. A., Ansar, R., Naeem, M. M., \& Yaqoob, S. (2017). Impact of FDI on economic growth: Evidence from Pakistan. Bulletin of Business and Economics, 6(3), 111-116.

Slemrod, J. (1990). BTax Effects on Foreign Direct Investment in the US: Evidence from a Crosscountry Comparison, ${ }^{\wedge}$ in: Assaf Razin and Joel Slemrod (eds.), Taxation in the Global Economy. In: Chicago, IL: University of Chicago Press.

Veugelers, R. (1991). Locational determinants and ranking of host countries: an empirical assessment. Kyklos, 44(3), 363-382.

WDI. (2021). World Develpment Indicatorss. Retrieved from https://databank.worldbank.org/source/world-development-indicatorss

World Bank. (2018). World bank National Accounts Data. Retrieved from https://data.worldbank.org/indicator/NY.GDP.MKTP.CD

Yang, X., \& Shafiq, M. N. (2020). The Impact of Foreign Direct Investment, Capital Formation, Inflation, Money Supply and Trade Openness on Economic Growth of Asian Countries. iRASD Journal of Economics, 2(1), 25-34.

\section{Appendix}

Table A: List of variables, Units and Data sources

Variables

Definition and Units of Analysis Dependent Variable

\begin{tabular}{|c|c|c|}
\hline variables & DeiInition ana Units or Analysis & sources \\
\hline \multicolumn{3}{|c|}{ Dependent Variable } \\
\hline $\begin{array}{l}\text { FDI } \\
\text { (Foreign Direct } \\
\text { Investment }\end{array}$ & $\begin{array}{l}\text { "Foreign direct investment are the net inflows of investment to acquire a } \\
\text { lasting management interest ( } 10 \text { percent or more of voting stock) in an } \\
\text { enterprise operating in an economy other than that of the investor. It is } \\
\text { the sum of equity capital, reinvestment of earnings, other long-term } \\
\text { capital, and short-term capital, as shown in the balance of payments. This } \\
\text { series shows net inflows (new investment inflows less disinvestment) in } \\
\text { the reporting economy from foreign investors and is divided by GDP." (\% } \\
\text { of GDP) }\end{array}$ & WDI (2021) \\
\hline \multicolumn{3}{|c|}{ Independent Variable } \\
\hline $\begin{array}{l}\text { TAX } \\
\text { (Tax rate) }\end{array}$ & $\begin{array}{l}\text { "Tax rate refers to compulsory transfers to the central government for } \\
\text { public and private purposes. A tax rate is a percentage at which an } \\
\text { individual or corporation is taxed." ( } \% \text { of GDP) }\end{array}$ & ESP (2020) \\
\hline \multicolumn{3}{|c|}{ Control Variables } \\
\hline $\begin{array}{l}\text { GDPG } \\
\text { (GDP growth) }\end{array}$ & $\begin{array}{l}\text { "Annual percentage growth rate of GDP at market prices based on } \\
\text { constant local currency. Aggregates are based on constant } 2005 \text { U.S. } \\
\text { dollars. GDP is the sum of gross value added by all resident producers in } \\
\text { the economy plus any product taxes and minus any subsidies not } \\
\text { included in the value of the products. It is calculated without deductions } \\
\text { for depreciation of fabricated assets or depletion and degradation of } \\
\text { natural resources." (annual \%) }\end{array}$ & WDI $(2021)$ \\
\hline $\begin{array}{l}\text { TRADEO } \\
\text { (Trade } \\
\text { openness) }\end{array}$ & $\begin{array}{l}\text { "Trade openness is the sum of exports and imports of goods and services } \\
\text { measured divided by gross domestic product." (\% of GDP) }\end{array}$ & WDI $(2021)$ \\
\hline $\begin{array}{l}\text { EXR } \\
\text { (Exchange } \\
\text { Rate) }\end{array}$ & $\begin{array}{l}\text { "Real effective exchange rate is the nominal effective exchange rate (a } \\
\text { measure of the value of a currency against a weighted average of several } \\
\text { foreign currencies) divided by a price deflator or index of costs." } \\
\text { Index }(2010=100)\end{array}$ & WDI (2021) \\
\hline $\begin{array}{l}\text { INR } \\
\text { (Interest Rate) }\end{array}$ & $\begin{array}{l}\text { "Real interest rate is the lending interest rate adjusted for inflation as } \\
\text { measured by the GDP deflator. The terms and conditions attached to } \\
\text { lending rates differ by country, however, limiting their } \\
\text { comparability."(Measured in \%) }\end{array}$ & WDI (2021) \\
\hline
\end{tabular}

